\title{
GAMBARAN KUALITAS TIDUR PADA PERAWAT DINAS MALAM RSUP PROF. DR. R. D. KANDOU MANADO
}

\author{
${ }^{1}$ Ricky R. T. A. Thayeb \\ ${ }^{2}$ Mieke A. H. N. Kembuan \\ ${ }^{2}$ Herlyani Khosama
}

\author{
${ }^{1}$ Kandidat Skripsi Fakultas Kedokteran Universitas Sam Ratulangi Manado \\ ${ }^{2}$ Bagian Neurologi RSUP Prof. Dr. R. D. Kandou Manado \\ Email: thayebrifa@gmail.com
}

\begin{abstract}
Sleep is one of the primary needs of the basic requirement for human survival. Sleep disorders can cause some effects in humans. It is estimated that $60-80 \%$ of workers with shift work system have impaired sleep quality. This results in a decrease in work productivity and an increase in the occurence of accidents. This study aimed to obtain the sleep quality of nurses in Prof. Dr. R. D. Kandou Hospital Manado in 2013. This was a descriptive and observational study by using questionnaires. The study population was nurses in the Neurology Department and the Emergency Department (ED) with samples of 52 people. The results showed that the subjective sleep qualities as perceived by the nurses themselves were as follows: good enough (44.23\%) and poor (36.54\%). Respondents that had sleep disturbance less than once a week were $30.77 \%$, and respondents that had sleep disturbance $1-2$ times a week were 59.62\%. Most nurses (69.24\%) did not use sleeping pills. Respondents that experienced some disruption of their activities during the day over the past 1 month as many as $1-2$ times a week were $55.77 \%$. Conclusion: The quality of sleep of night shift nurses in Prof. Dr. R. D Kandou Hospital Manado belonged to poor quality.
\end{abstract}

Keywords: night shift nurse, sleep quality

\begin{abstract}
Abstrak: Tidur merupakan salah satu kebutuhan primer yang menjadi syarat dasar bagi kelangsungan hidup manusia. Gangguan tidur dapat menimbulkan beberapa efek pada manusia. Salah satu hal yang menjadi perhatian adalah 60-80\% pekerja dengan system kerja shift mengalami gangguan kualitas tidur. Hal ini mengakibatkan penurunan produktivitas kerja dan dapat menyebabkan kecelakaan. Penelitian ini bertujuan untuk mengetahui gambaran kualitas tidur perawat di RSUP. Prof. Dr. R. D. Kandou Manado tahun 2013. Penelitian ini menggunakan metode deskriptif observasional dan pemberian kuesioner. Populasi ialah perawat Instalasi inap neurologi dan Instalasi gawat darurat (IGD dengan sampel berjumlah 52 orang. Hasil penelitian memperlihatkan kualitas tidur subjektif menurut persepsi perawat itu sendiri ialah cukup baik (44,23\%) dan kurang baik (36,54\%); gangguan tidur kurang dari sekali dalam seminggu (30,77\%); dan gangguan tidur 1-2 kali dalam seminggu (59,62\%). Mengenai penggunaan obat tidur, sebagian besar perawat $(69,24 \%)$ tidak menggunakan obat tidur. Mengenai perawat yang mengalami gangguan beberapa aktifitas di siang hari selama 1 bulan terakhir sebanyak 1-2 kali dalam seminggu yaitu sebesar 55,77\%. Simpualn: Kualitas tidur perawat dinas malam di RSUP Prof. Dr. R. D Kandou Manado tergolong kualitas tidur yang buruk.
\end{abstract}

Kata kunci: perawat dinas malam, kualitas tidur

Tidur merupakan salah satu kebutuhan primer yang menjadi syarat dasar bagi kelangsungan hidup manusia. Tidur adalah suatu keadaan tidak sadar dimana persepsi 
dan reaksi individu terhadap lingkungan menurun atau hilang, dan dapat dibangunkan kembali dengan indera atau rangsangan yang cukup. Gangguan tidur dapat menimbulkan beberapa efek pada manusia. Ketika kurang tidur seseorang akan berpikir dan bekerja lebih lambat, membuat banyak kesalahan, dan sulit untuk mengingat sesuatu. Hal ini mengakibatkan penurunan produktivitas kerja dan dapat menyebabkan kecelakaan. ${ }^{1,2}$

Prevalensi gangguan kualitas tidur setiap tahunnya cenderung meningkat, hal ini juga sesuai dengan peningkatan usia dengan berbagai penyebabnya. Salah satu penyebab dari kelelahan adalah kualitas tidur yang buruk. Apabila kecukupan tidur dari pekerja terganggu, maka akan dapat menimbulkan terjadinya kelelahan kerja. National Highway Traffic Safety Administration Amerika telah menghitung bahwa lebih dari 100.000 kecelakaan mobil setiap tahun berhubungan dengan faktor kelelahan. Kecelakaan mobil karena mengantuk terhitung sebanyak 1500 orang tewas dan puluhan ribu lainnya terluka dan cacat tetap. Diperkirakan tiap tahun 20\% $40 \%$ orang dewasa mengalami gangguan kualitas tidur dan $17 \%$ diantaranya mengalami masalah serius. Berdasarkan data mengenai kecelakaan kerja yang tercatat di Kompas tahun 2004, di Indonesia setiap hari rata-rata terjadi 414 kecelakaan kerja, 27,8\% disebabkan kelelahan yang cukup tinggi. ${ }^{3-5}$

Berdasarkan permasalahan tersebut peneliti tertarik untuk meneliti sejauh mana gambaran kualitas tidur pada perawat dinas malam di RSUP Prof. Dr. R. D. Kandou Manado.

\section{METODE PENELITIAN}

Penelitian ini menggunakan metode deskriptif observasional dan pemberian kuesioner. Penelitian ini dilaksanakan pada bulan Desember 2013 di RSUP. Prof. Dr. R. D. Kandou Manado. Populasi penelitian ini ialah seluruh perawat dinas malam di Instalasi Inap Neurologi dan Bagian
Instalasi Gawat Darurat RSUP Prof. Dr. R. D. Kandou Manado. Penentuan sampel pada penelitian ini menggunakan rumus Slovin dengan jumlah sampel sebanyak 52 orang responden.

\section{HASIL PENELITIAN DAN BAHASAN Karakteristik Responden}

Karakteristik usia dalam penelitian ini yang terbanyak yaitu responden yang berusia 20-30 tahun dan 31-40 tahun. Dari data ini bisa disimpulkan bahwa responden yang terlibat dalam penelitian ini terbanyak merupakan usia dewasa muda yang merupakan usia produktif. Hal ini sesuai dengan penelitian yang dilakukan Kodrat yang melibatkan pekerja shift yang terdiri dari usia $20-30$ tahun $(47,4 \%)$ dan usia $31-$ 40 tahun (50\%). Usia dewasa muda kebutuhan tidurnya rata-rata 6 sampai 8,5 jam per hari. Gaya hidup dapat mengganggu kualitas tidur dan pola tidur dewasa muda, seperti stres pekerjaan, hubungan keluarga, dan aktivitas sosial. ${ }^{7}$

Berdasarkan jenis kelamin dari data responden didapatkan jenis kelamin hampir berimbang yaitu responden yang berjenis kelamin perempuan $53,85 \%$ dan yang jenis kelamin laki-laki yaitu 46,16\%. Hal ini dapat terjadi karena pengambilan sampel dilakukan secara acak sehingga baik populasi laki-laki maupun perempuan memiliki peluang yang sama untuk terpilih sebagai responden.

Berdasarkan data tingkat pendidikan menunjukan hasil yang hampir berimbang yaitu S1 (strata 1) (57,69\%) dan D3 (diploma) (42,31\%). Hal ini dapat terjadi karena pengambilan sampel dilakukan secara acak sehingga populasi yang memiliki tingkat pendidikan S1 dan D3 memiliki peluang yang sama untuk terpilih menjadi responden.

Untuk status perkawinan diperoleh data yang terbanyak ialah responden yang sudah menikah (59,62\%). Status perkawinan sangat memengruhi tidur pekerja shift. Pekerja yang sudah menikah cenderung mengalami gangguan kualitas 
tidur yang lebih tinggi karena bertambanya tanggung jawab terhadap keluarga seperti istri atau suami dan anak-anak. Pekerja yang belum menikah lebih bebas memulai tidur kapan saja ketika selesai berkerja tanpa harus terbebani oleh tugas-tugas. ${ }^{4}$

Berdasarkan masa kerja ditemukan bahwa perawat yang mengalami masa kerja kurang dari 4 tahun jumlahnya jauh lebih besar dibandingkan dengan jumlah perawat yang mengalami masa kerja shift lebih dari 4 tahun, sehingga yang mengalami gangguan kualitas tidur lebih banyak pada perawat yang mengalami masa kerja shift kurang dari 4 tahun. Hal ini sejalan dengan penelitian Bohle yang menyatakan gangguan kualitas tidur biasa terjadi pada 5 tahun pertama atau masa adaptasi. Jika ditinjau secara teoritis masalah serius baru akan terjadi pada saat masa kerja shift mencapai 30 tahun, karena efek dari kerja shift pada gangguan kualitas tidur bersifat akumulasi. $^{4}$

\section{Kualitas Tidur}

Hal ini bisa dilihat berdasarkan komponen-komponen dalam kualitas tidur. Komponen 1 ditemukan kualitas tidur subjektif menurut persepsi perawat itu sendiri mengatakan kualitas tidur mereka cukup baik $(44,23 \%)$ dan kurang baik (36,54\%). Pada komponen ini merupakan penilaian perawat terhadap kualitas tidur mereka selama sebulan terakhir.

Komponen kedua (latensi tidur) ditemukan sebanyak 28,85\% membutuhkan waktu 16-30 menit untuk dapat tertidur dan 50\% membutuhkan waktu 31-60 menit untuk dapat tertidur. Pada orang normal waktu yang diperlukan untuk dapat tertidur adalah 10-15 menit. Faktor yang dapat mempengaruhinya antara lain kebiasaan makan sebelum tidur, kebiasaan merokok dimana kebiasaan ini dapat mengganggu tidur seseorang yang berdampak pada meningkatnya latensi tidur. ${ }^{7}$

Komponen ketiga (lama tidur) ditemukan hasil durasi tidur responden terbanyak ialah kurang dari 5 jam (51,92\%). Durasi tidur normal usia dewasa
7-8 jam per hari. Hal ini dapat terjadi akibat dari profesi kerja perawat itu sendiri yang harus tanggap dalam merawat pasien. Durasi tidur yang tidak cukup dapat memengaruhi kesehatan tubuh kita. ${ }^{8}$

Komponen keempat (efesiensi tidur) ditemukan hasil responden yang memiliki kebiasaan tidur dalam rentang $\geq 85 \%$ Sebanyak (38,46\%)responden. Sedangkan kebiasaan tidur dalam rentan $<65 \%$ sebanyak (30,77\%). Efisiensi ini dapat diketahui dengan membandingkan waktu tidur sebenarnya dengan lama waktu seseorang ketika berada di tempat tidur kemudian dikalikan dengan 100\%. Jumlah yang lebih dari $84 \%$ menunjukan bahwa tidur orang tersebut efisien dan jika kurang dari itu dikatakan tidak efisien. ${ }^{7}$

Komponen kelima (gangguan tidur) ditemukan sebanyak 30,77\% responden mengalami gangguan tidur kurang dari sekali dalam seminggu dan 59,62\% responden mengalami gangguan tidur 1 sampai 2 kali dalam seminggu. perawat dalam hal ini gangguan tidur terjadi karena adanya gangguan pada irama sirkardian dimana terjadi pergeseran pada siklus irama tidur danirama bangun. Gangguan ini dapat terjadikarena pola kerja shift. ${ }^{9}$

Komponen 6 (penggunaan obat tidur) ditemukan hasil yaitu sebagian besar perawat tidak menggunakan obat tidur yaitu sebanyak $(69,24 \%)$ responden.Hal ini dapat disebabkan karena gangguan kualitas tidur pada masing-masing perawat yang berbeda-beda dan dapat juga disebabkan karena perawat merupakan tenaga kesehatan sehingga mengerti bahwa mengkonsumsi obat tidur dapat menimbulkan efek yang tidak baik. Penggunaan dari obat tidur dapat mengganggu tahap III dan IV tidur REM dimana pada obat tidur ini menekan fase tidur REM yang dapat menyebabkan seringnya terjaga pada malam hari. ${ }^{4,7}$ Hal ini sejalan dengan yang diungkapkan oleh Colligan dalam pada penjelasan di atas. Menurut Colligan, penggunaan obat tidur yang berlebih tidak dianjurkan bagi seseorang untuk terbiasa mengkonsumsinya (misalnya lebih dari 
satu atau dua kalidalam seminggu) karena belum ada penelitian pada pekerja shift danpenggunaan obat tidur dalam jangka waktu yang lama. Penggunaan obat tidur oleh pekerja shift di setiap waktu pada saat mereka ingin tertidur sepanjang hari bukan merupakan jalan keluar yang baik. Pada beberapa orang dimana obat tidur dapat diperoleh dengan mudah, mereka selalu menggunakan obat tidur ketika ingin tertidur. Apabila hal ini terus berlangsung, orang tersebut akan menjadi gelisah atau mudah marah jika konsumsi obat tidur dihentikan. Penggunaan obat tidur dalam waktu yang lama akan menimbulkan rasa kantuk yang berlebihan setelah terbangun dari tidur. ${ }^{4}$

Komponen terakhir (disfungsi siang hari) menunjukkan bahwa sebagian perawat pada komponen ke tujuh mengalami gangguan beberapa aktifitas di siang hari mereka (saat mengendarai, saat makan dan kegiatan lainnya) selama 1 bulan terakhir sebanyak 1-2 kali dalam seminggu yaitu 55,77\%. Gangguan ini dapat terjadi karena kegiatan pada malam hari seperti shift malam menyebabkan seseorang merasa letih sehingga merasa mengantuk saat bekerja keesokan harinya. Hal ini juga diperkuat oleh literatur yang menyebutkan bahwa tidur yang pendek pada siang hari akan mengganggu tidur pada malam hari dan sebaliknya. ${ }^{10}$

Kualitas tidur merupakan variabel dependen dalam penelitian ini. Penilaian kualitas tidur responden menggunakan kuesioner Pittsburgh Sleep Quality Index (PSQI). Dari hasil penelitian ini dapat diketahui bahwa sebagian besar perawat pada kelompok perawat shift malam (84,62\%) memiliki kualitas tidur yang buruk. Hal ini juga sejalan dengan penelitian Juliana yang menyatakan bahwa 92\% perawat di unit rawat inap memiliki kualitas tidur buruk karena oleh pengaruh kerja shift. Hasil ini sesuai juga dengan hasil penelitian yang dilakukan oleh Padula dan De Abrau yang meneliti tentang penilaian kualitas tidur dan kantuk pada pekerja shift di Brazil yang melibatkan 94 responden yaitu pekerja shift 75 responden laki-laki dan 19 responden perempuan. Hasil penelitian yang didapati sebanyak $63,1 \%$ responden perempuan memiliki kualitas tidur yang buruk dan 26,3\% mengalami berbagai macam gangguan tidur sedangkan 64\% responden laki-laki memiliki kualitas tidur yang buruk dan $12 \%$ mengalami berbagai macam gangguan tidur. ${ }^{7,10}$

\section{SIMPULAN}

Berdasarkan hasil penelitian yang telah dilakukan maka dapat disimpulkan bahwa:

1. Hampir separuh responden mempunyai kualitas tidur subjektif cukup baik.

2. Lebih dari tiga perempat responden mempunyai latensi tidur yang lama (>15 menit).

3. Hampir separuh responden mempunyai durasi tidur $<5$ jam.

4. Hampir separuh responden menunjukkan nilai efesiensi yang belum memuaskan karena memiliki kualitas tidur yang tidak efisien.

5. Sebagian besar perawat tidak menggunakan obat tidur.

6. Lebih dari separuh responden mengalami gangguan aktifitas di siang hari $\geq 1$ kali dalam seminggu.

7. Kualitas tidur perawat dinas malam di RSUP Prof. Dr. R. D Kandou Manado tergolong buruk.

\section{SARAN}

Bagi peneliti selanjutnya diharapkan meneliti mengenai faktor-faktor yang dapat memengaruhi kualitas tidur perawat dinas malam.

Bagi Perawat Dinas Malam dapat diberikan penyuluhan tentang hiegine tidur supaya dapat memperpendek latensi tidur. Perawat disarankan untuk istirahat sebelum bekerja dinas malam agar dapat bekerja secara optimal.

Bagi Rumah Sakit diharapkan meninjau kembali jadwal shift kerja untuk menjaga kesegaran dan kewaspadaan pada 
saat bekerja agar kualitas pekerjaan tetap terjaga. Dilakukanya pelayanan konseling kesehatan terkait kondisi fisik dan mental sebelum dan selama pergantian waktu dinas malam serta menambah wawasan untuk perawat yang bertugas dinas malam.

\section{DAFTAR PUSTAKA}

1. Silvanasari IA. Faktor-Faktor Yang Berhubungan dengan Kualitas Tidur Yang Buruk pada Lansia di Desa Wonojati Kecamatan Jenggawah Kabupaten Jember [Skripsi]. Jember: Universitas Jember; 2012.

2. Puteri RK. Gambaran Stres Kerja Pada Perawat Shift Malam di Ruangan Instalasi Gawat Darurat RSUD dr. Pirngadi, Medan [Skripsi]. Medan: Universitas Sumatera Utara; 2009.

3. Nurlela S, Saryono, Yuniar I. Faktorfaktor yang Mempengaruhi Kualitas Tidur Pasien Post Operasi Laparatomi di Ruang Rawat Inap Rumah Sakit PKU Muhammadiyah Gombong. Jurnal Ilmiah Kesehatan Keperawatan. 2009;5(1):27-33.

4. Alawiyah T. Gambaran gangguan pola tidur pada perawat di RS. Syarif Hidayatullah, Jakarta [Skripsi]. Jakarta: Universitas Islam Negeri Syarif Hidayatullah; 2009.
5. Ihsan T, Salami IR. Hubungan Antara Shifts Kerja dengan Tingkatan Kelelahan Kerja pada Pekerja di Pabrik Perakitan Mobil Indonesia. Fakultas Teknik Sipil dan Lingkungan. Institut Teknologi Bandung [Internet]. 2007. Available from: http//www.ftsl.itb.ac.id/wpcontent/25310006.pdf

6. Rahman MF. Pengaruh Shift Kerja terhadap Motivasi Berprestasi Pramuniaga. Malang [Skripsi]. Malang: Universitas Islam Negeri (UIN); 2008.

7. Agustin D. Faktor-faktor yang Mempengaruhi Kualitas Tidur pada Pekerja Shift di PT Krakatau Tirta Industri Cilegon [Skripsi]. Jakarta: Universitas Indonesia; 2013.

8. Doe N. Gangguan Tidur pada Perawat Pekerja Shift [Skripsi]. Salatiga: Universitas Kristen Satya Wacana; 2012.

9. Iskandar, Japardi. Gangguan Tidur [Tesis]. Medan: Universitas Sumatera Utara; 2002.

10.Safitri A, Ardani MH. Studi Komparatif Kualitas Tidur Perawat Shift dan Non Shift di Unit Rawat Inap dan Unit Rawat Jalan. Prosiding Konferensi Nasional PPNI Jawa Tengah, 2013. 